University of South Florida

DIGITAL COMMONS

Digital Commons @ University of

@ UNIVERSITY OF SOUTH FLORIDA

South Florida

1991

\title{
Symposium on Creative Writing in the K-12 Curriculum
}

Joseph M. Moxley

University of South Florida Department of English, moxley@usf.edu

Follow this and additional works at: https://digitalcommons.usf.edu/eng_facpub

\section{Scholar Commons Citation}

Moxley, Joseph M., "Symposium on Creative Writing in the K-12 Curriculum" (1991). English Faculty Publications. 157.

https://digitalcommons.usf.edu/eng_facpub/157

This Article is brought to you for free and open access by the English at Digital Commons @ University of South Florida. It has been accepted for inclusion in English Faculty Publications by an authorized administrator of Digital Commons@ University of South Florida. For more information, please contact digitalcommons@usf.edu. 


\section{November/December 1991 \\ Volume 93, Number 2}

m.t.

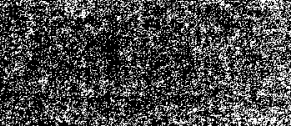

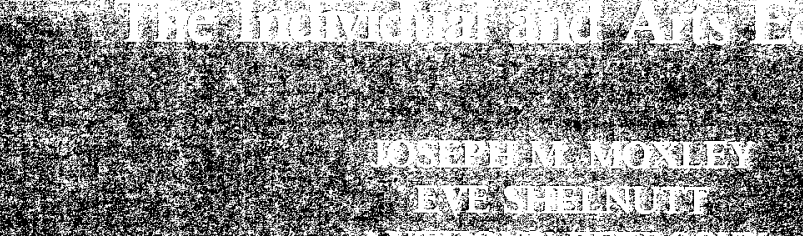

(1)

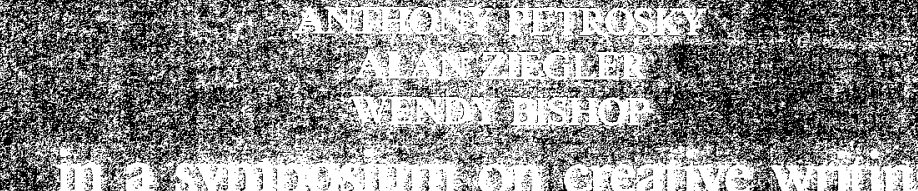

3

1.

T.1.

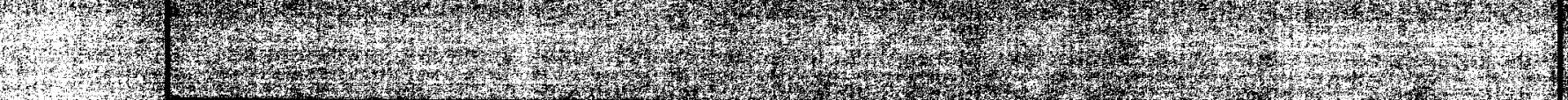

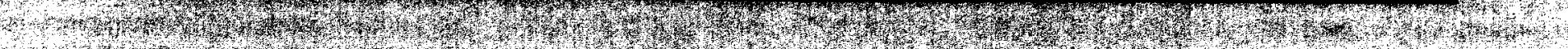

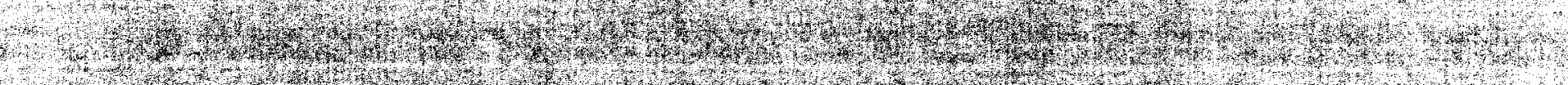

H. 


\section{SYMPOSIUM ON CREATIVE WRITING IN THE K-12 CURRICULUM}

W

hy do so few students enjoy writing or reading literature? What experiences in school or misperceptions about writing intrude on students' willingness or ability to engage their own imaginations? After all, writing is a fundamental mode of learning and exploration. By writing multiple drafts, we can integrate our thinking on various subjects, make connections between related phenomena and concepts, and further our understanding and recall of material.

Certainly, given our greater understanding of the significance of writing to learning and explorative thinking, we need to offer students countless opportunities to write nonfiction prose in the $\mathrm{K}-12$ curriculum. If we are to draw effectively on the generative nature of language, then our students should be writing about mathematical equations, biological concepts, and social processes. ${ }^{1}$

However, if we hope to facilitate a nation of readers and original thinkers-people who understand the arts and their significance to society-then we must introduce our students to the rigors and pleasures of writing fiction, poetry, and drama. By introducing students to these genres, we can offer them ways to express their experiences, thoughts, and problems in language. Beyond offering a cathartic release, these writing experiences will enable students to understand their own lives. By giving them the chance to write about the conflicts and behaviors that they confront daily, we can show students that language is a viable and powerful way to experiment with who we are and who we can be. Unfortunately, such experimentation through creative writing is at an all-time low in our schools. When Arthur Applebee studied writing in U.S. secondary schools, he dis- covered that very little creative writing was being assigned: of the writing that he examined, only 8.2 percent of the 182 ninth graders' work and 7.2 percent of the 167 eleventh graders' work involved writing stories or poems. ${ }^{2}$ (Current statistics on this subject are not available, but we predict that with education cutbacks, the situation will only get worse.) Before schools squeeze out the remaining time they allow this rich source of creative expression, administrators and teachers need to look closely at their curricula.

The following four essays address innovative ways of reshaping the $\mathrm{K}-12$ curriculum so that students can have a richer sense of how language can shape understanding and thought. In particular, in "Creative Writing Pedagogy: What the Specialist Can't Do," Eve Shelnutt analyzes how writing in different genres promotes creativity. Shelnutt enumerates reasons for incorporating daily creative writing into the curriculum and explores ways to train teachers to teach creative writing. In "The State of Poetry in the Schools," Anthony Petrosky suggests that introducing literature in a chronological order from the past to the present deadens students' interest in literature. Rather than beginning in the eighteenth century, Petrosky argues, it would make more sense to introduce students to modern literature, and he itlustrates ways that modern poetry can be introduced into the curriculum. Next, in "A High School Summer Curriculum," Alan Ziegler describes a rigorous curriculum that integrates the teaching of fiction, poetry, script writing, copy editing, and publishing. And in the final essay, "Teaching the Process of Creative Writing," Wendy Bishop analyzes the limitations of relying solely on models of professional writing. Bishop ex- 
plores the need for a "whole English" approach to teaching creative writing in the $\mathrm{K}-12$ curriculum and speculates that we need to spend less time telling students what they don't know and more time recognizing all that they do know. Instead of asking students to memorize rules out of the context of composing, Bishop provides numerous exercises that will enable students to "write into the rules"-that is, to purposely break the rules so that students can discover for themselves the reasoning behind them. Taken as a whole, we hope that these essays demonstrate that teaching creative writing is not an esoteric activity, but a fundamental way of understanding, learning, and changing the world. To help promote a nation of readers, we need to engage our students' imagination.

Notes

1. For more information about the relationship between thinking and learning, see Lev S. Vygot- sky, Thought and Language, ed. and trans. Eugenia Hanfmanna and Gertrude Vakar (Cambridge, England: MIT Press, 1962); Janet Emig, "Writing as a Mode of Learning," College Composition and Communication 28(May 1977):122-28; and Arthur Applebee and Judith Langer, How Writing Shapes Thinking (Urbana, Ill.: National Council of Teachers of English, 1987).

2. Applebee, note 1 above, 36 .

Joseph M. Moxley, coordinator Sally Stoval

Joseph M. Moxdey, an associate professor of English at the University of South Florida, is editor of Creative Writing in America: Theory and Pedagogy (National Council of Teachers of English, 1989). Sally Stoval, who teaches eighth-grade English at Shorecrest Preparatory School, recently completed her first novel.

\section{American Alliance for Theatre \& Education 1991 RESEARCH AWARD}

The AMERICAN ALLIANCE FOR THEATRE AND EDUCATION RESEARCH AWARD is given annually for significant naturalistic/ethnographic, empirical/quantitative, descriptive/qualitative, theoretical, critical, historical, or other scholarly research in the areas of Drama (creative drama, socio-dramatic play, informal role-playing, improvisation); Theatre for Young Audiences/Children's Theatre (formal theatre produced by, for, or with children and/or adolescents); and/or Drama/Theatre Education (preschool through grade 12). Research previously published in related scholarly journals is acceptable. Six abstracts and one copy of the study, if completed, should be sent with name, address, and telephone by January 15, 1992 to:

\section{Holly Giffin, AATE Research Chair \\ P.O. Box 4057 \\ Boulder, CO 80306}

Further detailed guidelines will be sent upon submission or request. Five completed copies of the finished study must be available, upon the request of the jury, by March 15th, 1992. Award finalists will be expected to present their research at the annual AATE convention to be held August 5-9 in Seattle, Washington, and to submit summary papers to the Youth Theatre Journal for potential publication. 